\title{
KOMUNIKASI MILITER PADA REMAJA DALAM MENGAMBIL KEPUTUSAN MENJADI PRAJURIT TNI-AD DI KOREM 062 TARUMANAGARA GARUT
}

\author{
Devi Prayoga ${ }^{1}$, Achmad Wildan Kurniawan ${ }^{2}$, lis Zilfah Adnan ${ }^{3}$, \\ Zikri Fachrul Nurhadi ${ }^{4}$, \\ 1,2,3,4 Program Studi Ilmu Komunikasi, Konsentrasi Public Relations, Universitas Garut \\ e-mail: deviprayoga24@gmail.com1, iiszilfahadnan@uniga.ac.id2, \\ achmadwildan@uniga.ac.id3, zikri_fn@uniga.ac.id4* \\ *Corresponding author: zikri fn@uniga.ac.id
}

\begin{abstract}
Abstrak
Penelitian ini dilatarbelakangi oleh banyaknya remaja yang mendaftarkan diri menjadi prajurit TNI-AD. Hal ini, tidak dipungkiri bahwa mereka memiliki tujuan tersendiri. Setiap tahun pendaftaran TNI-AD khususnya di Garut Kota terus meningkat. Hal ini, menjadi fenomena baru di mana dulu jarang sekali orang yang ingin menjadi seorang prajurit dan mengabdikan dirinya kepada negara. Batasan usia pendaftaran menjadi seorang prajurit yaitu 18-22 tahun bagi remaja lulusan SMA atau sederajatnya. Memasuki dunia militer ini harus memiliki mental dan fisik yang kuat terutama harus pandai dalam berkomunikasi dengan bawahan maupun dengan atasan agar tidak terjadi suatu miss communication pada saat bertugas. Adapun tujuan penelitian ini adalah untuk menemukan dan menjelaskan tentang motif, pengalaman, dan makna remaja menjadi prajurit TNI-AD. Penelitian ini menggunakan pendekatan deskriptif kualitatif. Teknik pengumpulan data melalui cara wawancara mendalam, observasi partisipan, dan studi pustaka. Adapun informan dalam penelitian sebanyak 8 orang. Hasil penelitian menunjukkan bahwa motif untuk menjadi parjurit TNI-AD adalah cita-cita dan ekonomi, sedangkan motif karena rasa nasionalisme, keluarga dan lingkungan sekitar. Pengalaman yang ada yaitu tinggal di lingkungan militer, mengikuti organisasi-organisasi di sekolah, pengaruh game online action, adanya didikan keluarga sejak kecil.
\end{abstract}

Kata Kunci : Komunikasi, Militer, Remaja, Prajurit, TNI-AD

\footnotetext{
ABSTRACT

This research is motivated by the number of teenagers who register themselves as an Army soldier is not denied that they have their own goals. Every year registration of TNI-AD especially in Garut City continues to increase. This is a new phenomenon where rarely had anyone wanted to be a soldier and devote himself to the state. The age limit of registration to become a soldier is 18-22 years old for high school graduates or equivalent. Entering the military world must have a strong mental and physical, especially must be good at communicating with subordinates and with superiors to avoid a miss communication at the time of duty. The purpose of this study is to find and explain about the motives, experiences, and meaning of adolescents as soldiers of the Army. This research use desciptive qualitative approach. Data collection techniques through in-depth interviews, participant observation, and
} 
literature study. The informants in the study as many as 8 people. The results showed that the motive for being a TNI-AD par excellence is the aspiration and economy, while the motive is due to the sense of nationalism, family and the environment. The existing experience of living in military environments, following organizations in schools, the influence of online action games, the existence of family education since childhood.

Keywords : Communication, Military, Youth, Soldiers, Army

\section{PENDAHULUAN}

Komunikasi militer melibatkan semua aspek komunikasi, penyampaian informasi serta membuat strategi. Menurut Lestari (2012) komunikasi militer didefinisikan sebagai konstruksi dan bangunan militer yang didesain untuk pertahanan dalam perang. Komponen atau variabel pada komunikasi militer mencakup beberapa bagian, yaitu senjata militer, armor, munisi, kendaraan darat militer, kendaraan militer udara, robot militer (Lestari, 2012). Berdasarkan gambaran komunikasi militer maka memberikan dampak kepada perkembangan teknologi komunikasi dan cara berpikir manusia yang ditandai dengan banyaknya remaja yang mendaftarkan diri menjadi seorang prajurit TNI-AD tidak dipungkiri bahwa mereka memiliki tujuan tersendiri. Setiap tahun pendaftaran TNI-AD khususnya di daerah Garut Kota terus meningkat. Hal ini, menjadi fenomena baru di mana dulu jarang sekali yang ingin menjadi seorang prajurit dan mengabdikan dirinya kepada negara. Batasan usia pendaftaran pun menjadi pusat perhatian seorang ketika menjadi prajurit, yaitu 18-22 tahun bagi remaja lulusan SMA atau sederajatnya. Memasuki dunia militer ini harus memiliki mental dan fisik yang kuat terutama harus pandai dalam berkomunikasi dengan bawahan maupun dengan atasan agar tidak terjadi suatu miss communication pada saat bertugas. Maka dari itu, menjadi seorang prajurit harus mengerti dan memahami komunikasi yang efektif agar pesan yang disampaikan dapat diterima langsung dengan baik.

Tentunya, pernyataan yang dijelaskan sebelumnya sebagai wujud rasa cinta tanah air kepada bangsa dan Negara Kesatuan Republik Indonesia. Hal ini, harus ditanamkan kepada anak sejak usia dini baik pada lingkungan keluarga dan sekolah. Menanamkan rasa cinta tanah air pada anak bisa melalui berbagai cara, misalnya dengan upacara sederhana setiap hari Senin dengan menghormati bendera Merah Putih, menyanyikan lagu kebangsaan Indonesia Raya, dan mengucapkan Pancasila. Cinta tanah air adalah perasaan yang timbul dari dalam hati seorang warga Negara, untuk mengabdi, memelihara, membela, melindungi tanah airnya dari segala ancaman dan gangguan. Maka dari itu, khususnya remaja pada masa ini harus bisa mencintai dan menghargai negara dengan caranya sendiri, maka negara Indonesia ini akan dapat berkembang lebih baik. Generasi muda, khususnya para remaja merupakan calon atau bibit penerus bangsa yang akan menjalankan negara kelak. Keputusan ini harus dibentuk sejak dini hingga tertanam di dalam dirinya masing-masing. Berdasarkan data hasil wawancara, didapat hasil perkembangan pendaftaran TNI-AD berdasarkan data dari Ajenrem 062 Tarumanagara dapat dilihat pada tabel 1: 
Tabel 1. Pendaftaran Tahun 2013-2016 di Anjenrem 062 Tarumanagara

\begin{tabular}{|c|c|}
\hline $\begin{array}{c}\text { Tahun Pendaftaran } \\
2013 \\
\end{array}$ & Jumlah \\
\hline $\begin{array}{l}\text { a. Catam Gelombang I } \\
\text { b. Catam Gelombang II } \\
\text { c. Caba Pria } \\
\text { d. Caba Wanita } \\
\text { e. Akmil }\end{array}$ & $\begin{array}{l}\text { a. } 187 \text { Orang } \\
\text { b. } 241 \text { Orang } \\
\text { c. } 201 \text { Orang } \\
\text { d. } 12 \text { Orang } \\
\text { e. } 43 \text { Orang }\end{array}$ \\
\hline Pendaftar & Jumlah \\
\hline $\begin{array}{ll}\text { a. } & \text { Catam Gelombang I } \\
\text { b. Catam Gelombang II } \\
\text { c. Caba Pria } \\
\text { d. Caba Wanita } \\
\text { e. Akmil }\end{array}$ & $\begin{array}{l}\text { a. } 190 \text { Orang } \\
\text { b. } 265 \text { Orang } \\
\text { c. } 210 \text { Orang } \\
\text { d. } 25 \text { Orang } \\
\text { e. } 54 \text { Orang }\end{array}$ \\
\hline $\begin{array}{l}\text { Tahun Pendaftaran } \\
\qquad 2015\end{array}$ & Jumlah \\
\hline $\begin{array}{l}\text { a. Catam Gelombang I } \\
\text { b. Catam Gelombang II } \\
\text { c. Caba Pria } \\
\text { d. Caba Wanita } \\
\text { e. Akmil }\end{array}$ & $\begin{array}{ll}\text { a. } & 200 \text { Orang } \\
\text { b. } & 270 \text { Orang } \\
\text { c. } 225 \text { Orang } \\
\text { d. } 35 \text { Orang } \\
\text { e. } \quad \text { Pendaftaram di } \\
\text { Ajendam III } \\
\text { Siliwangi } \\
\text { (Bandung) }\end{array}$ \\
\hline $\begin{array}{c}\text { Tahun Pendafta } \\
2016\end{array}$ & Jumlah \\
\hline $\begin{array}{l}\text { d. Caba Wanita } \\
\text { e. Akmil }\end{array}$ & 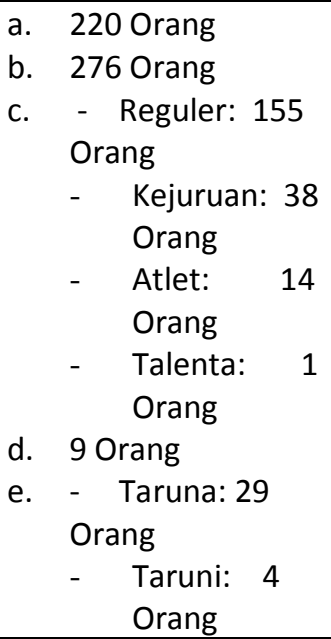 \\
\hline
\end{tabular}

Sumber : Ajenrem 062 Tarumanagara, Garut 2017

Pada tahun 2013 pendaftaran dan tes pandaftaran dilakukan di Korem 062 tarumanagara sehingga antusias remaja sangat banyak khususnya di Kabupaten Garut. Pada tahun 2016 merupakan tes panda terakhir yang dilakukan di Korem 062 Tarumanagara. Pada tahun-tahun berikutnya, tes sub panda dilakukan di Bandung untuk wilayah Jawa Barat (Kodam III Siliwangi) tetapi pendaftaran bisa dilakukan di Korem 062 Tarumanagara untuk wilayah Garut dan sekitarnya. Pada tahun 2014 pendaftaran di Ajenrem sedikit menurun 
dikarenakan tes sub panda dilaksanakan di Bandung sehingga kebanyakan remaja di wilayah Garut dan sekitarnya langsung mendaftarkan diri ke Ajendam.

Pada tahun 2015 ada perubahan pendaftaran Akademi Militer yang tadinya bisa dilakukan pendaftaran di tiap korem, pada tahun ini untuk semua wilayah dipusatkan di tiaptiap Ajendam. Sehingga pada tahun ini tidak ada pendaftaran di tiap korem. Kemudian pada tahun 2016, dibukanya pendaftaran Caba dengan berbagai bidang atau keahlian tertentu seperti Caba Kejuruan yang dikhususkan untuk remaja lulusan Sekolah Menengah Kejuruan, Caba Atlet yang dikhususkan untuk atlet remaja yang memiliki prestasi di bidang olahraganya masing-masing, serta dibukanya Caba Talenta yaitu dikhususkan pada remaja yang memiliki talenta tertentu dalam berbagai macam bidang tertentu entah itu bidang musik, Matematika dan lain sebagainya.

Pada masa remaja ini seseorang sedang mencari identitasnya, dimana yang dijelaskan oleh Erikson sebagai konsepsi tentang diri, penentuan tujuan, nilai dan keyakinan yang dipegang teguh oleh seseorang menjadi fokus pada masa remaja (dalam Papalia, 2008:587). Masa remaja ini masa dimana seseorang ingin mencoba sesuatu hal yang baru dikenalnya. Emosional pada masa ini sangat tinggi sehingga harus dikontrol dengan sebaik mungkin. Tentara dan polisi masih dianggap sebagai profesi yang gagah dan macho. Meskipun dengan menjadi pasangan mereka, sang wanita harus rela ditinggal tugas ke medan perang, tetapi dibalik itu ada kebanggaan tersendiri. Berpasangan dengan para pembela negara yang pemberani adalah hal yang membuat banyak wanita bangga. Inilah salah satu alasan dimana remaja banyak yang mendaftarkan diri menjadi tentara maupun polisi. Tetapi mayoritas remaja mendaftarkan diri menjadi tentara hal ini yang membuat banyak pertanyaan kenapa profesi tentara lebih diminati dibandingkan dengan polisi bagi kaum pria.

"Menurut saya, para calon lebih memilih menjadi seorang prajurit TNI dibandingkan polisi karena TNI memiliki karisma tersendiri entah itu dari pakaiannya yang membuat seseorang terlihat lebih gagah, dari lagu-lagu TNI yang memotivasi remaja maupun dari sikap yang telah dibentuk pada saat melasanakan pendidikan dasar. Selain itu, loyalitas dan faktor keluarga maupun lingkungan yang dapat menentukan pilihan para calon menjadi prajurit TNI".

Berdasarkan hasil wawancara dengan salah satu informan, bahwa keputusan menjadi seorang prajurit tidak lepas dari harapan dan motivasi seseorang. Harapan dan motivasi individu pasti berbeda-beda karena sesuai dengan perkembangan usia yang berbeda pula. Seseorang yang memilih untuk bekerja di suatu instansi sebaiknya sudah memikirkan keuntungan dan kerugian yang akan didapatnya serta diseimbangkan dengan potensi dan juga keinginannya.

Banyaknya remaja yang mendaftarkan diri menjadi seorang prajurit ini sesuai dengan tugas utama analisis fenomenologi yaitu:

Merekonstruksi dunia kehidupan manusia "sebenarnya" dalam bentuk yang mereka sendiri alami. Realitas dunia tersebut bersifat intersubjektif, dalam arti bahwa anggota masyarakat berbagai persepsi dasar mengenai dunia yang mereka internalisasikan melalui sosialisasi dan memungkinkan mereka melakukan interaksi atau komunikasi Mulyana (dalam Nurhadi, 2015:32).

Penelitian ini difokuskan di Korem 062 Tarumanagara, di mana dijadikan salah satu subpanda pendaftaran TNI-AD di Jawa Barat. Berdasarkan pengaamatan empitik peneliti terdapat hal yang unik di Korem 062 TN ini, yaitu setiap hari minggu terdapat pelatihan jasmani yang dibimbing langsung oleh orang Jasrem (Jasmani Korem) untuk melatih fisik dan mental remaja yang akan mendaftarkan diri ke TNI maupun Polri. Pelatihan ini dilakukan mulai dari pukul 08.30 sampai selesai dengan beberapa latihan diantaranya melakukan tes fisik lari, pull up, sit up, push up dan shuttle run. 
Hal ini menjadi menarik untuk diteliti karena peneliti berfokus pada kajian komunikasi militer khususnya para remaja dalam mengambil keputusan untuk menjadi prajurit TNI-AD calon prajurit TNI-AD. Dalam perkembangannya, seorang remaja mencari identitas diri dan mulai mencari tahu tentang pekerjaan yang sesuai dengan bakatnya. Kajian komunikasi militer ini diperkuat oleh penelitian terdahulu yang dilakukan oleh Riris (2015), tentang Pola Asuh Anak Pada keluarga Militer yang menunjukkan bahwa pola asuh yang diterapkan pada keluarga militer dipengaruhi dari habitus dan modal yang dimiliki oleh orang tua. Habitus yang dimiliki dilihat dari pengalaman individu tersebut ketika masih tinggal dengan orang tuanya. Sedangkan modal yang dimiliki ada empat yang pertama yakni modal ekonomi berupa materi, kedua yakni modal budaya berupa latar belakang pendidikan, ketiga yakni modal sosial berupa teman dalam pergaulan, keempat yakni modal simbolik berupa pangkat jabatan. Dari keempat modal itu juga mempengaruhi kesempatan sosial anak.

Berdasarkan paparan tersebut, peneliti merasa tertarik untuk meneliti lebih lanjut mengenai banyaknya remaja yang mendaftarkan diri menjadi prajurit TNI-AD di Kabupaten Garut khususnya remaja yang melakukan latihan di Korem 062 Tarumanagara. Adapun fokus masalah penelitian ini adalah bagaimana motif, pengalaman dan makna menjadi prajurit TNI$A D$ pada kalangan remaja. Sedangkan tujuan penelitian ini adalah untuk menemukan dan menjelaskan model komunikasi tentang motif, pengalaman dan makna Remaja Dalam Mengambil Keputusan Menjadi Prajurit TNI-AD di Korem 062 Tarumanagara. Oleh sebab itu peneliti mengambil judul tentang Komunikasi Militer Pada Remaja Dalam Mengambil Keputusan Menjadi Prajurit TNI-AD di Korem 062 Tarumanagara Garut.

\section{Metode Penelitian}

Penelitian ini menggunakan paradigma konstruktivisme adapun penjelasan secara rinci tentang paradigma konstruktivisme adalah paradigma yang memandang ilmu sosial sebagai analisis sistematis terhadap soially meaningfull action melalui pengamatan langsung dan rinci terhadap pelaku sosial dalam setting keseharian yang alamiyah, agar mampu memahami dan menafsirkan bagaimana para pelaku sosial yang bersangkutan menciptakan dan memelihara atau mengelola dunia sosial mereka (Nurhadi, 2017: 34). Dalam hal ini berkaitan dengan fokus penelitian ini di mana dilakukan pengamatan kepada remaja yang akan mendaftarkan diri menjadi prajurit TNI-AD agar mampu memahami faktor ataupun motivasi tertentu yang dimiliki oleh setiap individunya.

Sesuai dengan pradigma dan permasalahan yang di pilih dalam penelitian ini, maka penelitian ini menggunakan pendekatan kualitatif. Tujuan penelitian ini adalah untuk memahami apa yang tersembunyi di balik fenomena yang kadang kala merupakan sesuatu yang sulit untuk di pahami, peneliti ingin menggali pengalaman individu dalam mendefinisikan suatu permasalahan dan masyarakat yang menjadi informan bebas untuk mengungkapkan definisinya tersendiri.

Penelitian kualitatif mampu melukiskan kejadian atau realitas sosial dari sudut pandang subjek bukan dari sudut pandang peneliti sebagai pengamat. Hal- hal yang di teliti meliputi perilaku, perasaan dan emosi dari subjek penelitian. Demi mendapatkan pemahaman otentik, pengamatan dan wawancara mendalam (dengan tujuan pertanyaan-pertanyaan terbuka) di anggap sesuai dan potensial dengan tujuan penelitian tersebut. (Mulyana, 2007). Adapun teknik yang digunakan untuk menentukan informan dalam penelitian yaitu dengan jalan peneliti melakukan pengamatan atau langkah observasi lapangan dan wawancara kepada orang-orang yang di padang tahu tentang situasi tersebut (Sugiyono, 2013). Informan dipilih berdasarkan pertimbangan peneliti dengan tujuan tertentu (purposif sampling). Untuk sebuah studi fenomenologis kriteria informan yang baik adalah "all individuall studied refresent people who experienced the phenomenon", jadi pada penelitian ini informan yang dipilih oleh peneliti 
merupakan seseorang yang benar-benar terlibat dan mempunyai pengalaman untuk menjadi seorang prajurit TNI-AD.

Informan tersebut merupakan para remaja yang mengikuti pelatihan khusus jasmani di Korem 062 Tarumanagara. Jumlah informan yang akan diteliti sebanyak 8 orang. Penentuan 8 orang ini karena dilakukan pemilihan dari beberapa orang yang sebelumnya telah ditentukan sebelumnya. Adapun kriteria pemilihan informan pada penelitian ini adalah:

1. Memiliki keinginan yang kuat menjadi seorang prajurit;

2. Pernah mengikuti seleksi Akademi Militer pada tahun 2016;

3. Memiliki pengalaman yang membuatnya tertarik dan memutuskan menjadi seorang prajurit;

4. Berjenis kelamin wanita ataupun pria ;

5. Berumur 18-22 tahun;

6. Lulusan Sekolah Menengah Atas (SMA)/ sederajatnya, jurusan IPA;

7. Aktif mengikuti bimbingan jasmani di korem 062 Tarumanagara setiap hari minggu.

Berikut profile informan pada penelitian ini adalah:

Tabel 2

Profil Singkat Informan

\begin{tabular}{|l|l|l|l|l|l|}
\hline NO. & \multicolumn{1}{|c|}{ NAMA } & USIA & $\begin{array}{c}\text { TAHUN } \\
\text { LULUS } \\
\text { SMA }\end{array}$ & $\begin{array}{c}\text { TAHU } \\
\text { MASUK }\end{array}$ & $\begin{array}{c}\text { KATEGORI } \\
\text { SELEKSI }\end{array}$ \\
\hline 1. & Agung Prawira Subagja (L) & 20 Th & 2016 & 2016 & Taruna Akmil \\
\hline 2. & Aldi Muhammad Fakhri (L) & 19 Th & 2016 & 2016 & Taruna Akmil \\
\hline 3. & Dwiyana Ramdhani Setiawan (L) & 19 Th & 2016 & 2016 & Taruna Akmil \\
\hline 4. & $\begin{array}{l}\text { Muhamad Andrianto Wahidin } \\
\text { Fatkhanudin (L) }\end{array}$ & 19 Th & 2016 & 2016 & Taruna Akmil \\
\hline 5. & Muhamad Fadly (L) & 19 Th & 2016 & 2016 & Taruna Akmil \\
\hline 6. & Rani Pusdikawati (P) & $20 \mathrm{Th}$ & 2015 & 2016 & Taruni Akmil \\
\hline 7. & Sita Siti Azimah (P) & $20 \mathrm{Th}$ & 2015 & 2016 & Taruni Akmil \\
\hline 8. & Widya Mega Serdianty (P) & $19 \mathrm{Th}$ & 2016 & 2016 & Taruni Akmil \\
\hline
\end{tabular}

Sumber: Model kategorisasi pengamatan dan wawancara (diadopsi dari informan tahun 2017)

\section{HASIL PENELITIAN DAN PEMBAHASAN}

\section{Hasil Penelitian}

Setelah melakukan penelitian di lapangan selama beberapa bulan, peneliti memperoleh gambaran mengenai komunikasi militer pada remaja dalam mengambil keputusan menjadi prajurit TNI-AD di Korem 062 Tarumanagara. Peneliti juga menemukan halhal yang menarik pada saat terjun langsung ke lapangan bersama informan yang telah peneliti tentukan sebelumnya. Pada bagian ini, peneliti akan membahas mengenai hasil temuan di lapangan termasuk di dalamnya tahapan wawancara terstruktur dan tidak terstruktur, observasi dan studi pustaka. Peneliti akan membahas hasil penelitian dari sudut pandang peneliti yang didapatkan dengan menginterpretasikan hasil wawancara dan hasil observasi.

Proses penelitian dilaksanakan pada beberapa tempat yaitu Korem 062 Tarumanagara, Lapangan Merdeka (Kerkhof). Selain itu peneliti juga melakukan wawancara menggunakan media social WhatsAp. Penggunaan media social ini juga dikarenakan ada informan yang tidak bisa bertemu secara langsung dan untuk memperjelas wawancara yang sebelumnya telah dilakukan. Adapun hasil penelitian ini adalah:

Motif Remaja Menjadi Prajurit TNI-AD 
Banyaknya remaja yang mengikuti seleksi prajurit TNI-AD tidak dipungkiri lagi bahwa mereka memiliki motif masing-masing. Adapun motif yang mendasari para remaja menjadi prajurit TNI-AD seperti (informan 1) Agung Prawira Subagja mengatakan bahwa:

"Menjadi seorang prajurit adalah cita-cita saya dari kecil euuuu karna melihat ayah saya seorang anggota TNI-AD. Euuu jadi saya ingin seperti ayah saya, karna ketika saya melihat ayah serasa gagah dan berwibawa pas memakai baju loreng. Selain itu, mungkin karena faktor lingkungan dimana kebanyakan teman-teman saya orang-orang yang akan masuk TNI-AD jadi saya juga termotivasi".

Agung mengatakan bahwa menjadi seorang prajurit adalah cita-citanya dari kecil. la juga termotivasi oleh ayahnya yang merupakan seorang anggota TNI-AD. Selain itu faktor lingkungan yang sangat mempengaruhinya karena kebanyakan teman-temannya merupakan calon-calon prajurit di masa depan.

Faktor orang tua disini sangat mempengaruhi keputusannya dimana sejak kecil Agung sudah melihat ayahnya memakai seragam loreng. Hal ini membuktikan bahwa didikan orang tua akan menentukan sikap, perilaku, dan keinginan anaknya di masa yang akan datang. Sedangkan menurut (informan 2) Aldi Muhammad Fakhri motif yang mendasari dirinya mengatakan:

"Alasan saya menjadi prajurit yaitu, saya ingin mengabdikan diri saya kepada negara melalui TNI-AD. Menurut saya menjadi prajurit TNI-AD selain gagah tentara juga merupakan abdi negara yang mengabdikan dirinya kepada negara untuk menjaga NKRI, hal tersebut merupakan tugas yang mulia. Motif lain yang mendasari saya selain faktor keluarga, karena saya dibesarkan dikeluarga militer, saya juga terinspirasi dari tokoh-tokoh lainnya salah satunya yaitu Jenderal Soedirman, beliau sangat disegani oleh semua kalangan. Yang terakhir karena jika saya menjadi anggota TNI-AD, masa tua saya akan terjamin oleh negara".

Sedikit berbeda dengan Agung, motif yang mendasari Aldi karena rasa nasionalisme yang sangat tinggi. Keinginannya mengabdi pada negara sangat kuat dalam dirinya sehingga Aldi ingin menjadi seorang prajurit yang rela berkorban demi bangsa dan negaranya. Selain itu Aldi termotivasi oleh ayah dan kakaknya yang merupakan seorang anggota TNI-AD. Ayah nya bertugas di Korem 062 Tarumanagara sedangkan kakanya merupakan seorang Kowad yang sedang di tugaskan di Papua.

Dapat dilihat bahwa peranan orang tua dan keluarga sangat berpengaruh terhadap keputusan yang akan diambil oleh anaknya. Didikan militer yang diterapkan oleh keluarga militer pada anak-anaknya menyebabkan seorang anak patuh dan mengikuti sesuai dengan instruksi dari keluarganya. Pada dasarnya seorang anak akan mencontoh semua yang dikerjakan oleh orang tuanya, hal ini lah yang menyebabkan Aldi memustuskan untuk menjadi seorang prajurit. Tidak jauh berbeda dengan (informan 3) Dwiyana Ramdhani Setiawan, ia mengatakan bahwa:

"Ya ... mungkin karena faktor lingkungan sehingga saya ingin menjadi anggota TNI. Euuuuu saya juga kalo ditanya apa motifnya, saya gak bisa ngejawab secara langsung, soalnya sampai sekarang juga saya gak tahu kenapa saya sangat tertarik menjadi anggota TNI. Euuuu mungkin panggilan hati kayanya hahah ... selain itu dari keluarga juga banyak anggota TNI. Ya.. mungkin dari situlah saya mulai fokus pada masa depan saya untuk menjadi seorang prajurit".

Pengalaman Remaja Menjadi Prajurit TNI-AD

Pengalaman seseorang mempengaruhi keputusan yang akan diambil di masa yang akan datang. Maka dari itu pengalaman sangat berguna bagi setiap orang. Selain itu pengalaman setiap orang pasti memiliki perbedaan yang menonjol. Namun terkadang ada kesamaan yang sangat terlihat signifikan di mana hal tersebut bisa terjadi jika latarbelakang yang dimiliki setiap informan sama. Berikut hasil dari wawancara mengenai pengalaman dengan (informan 1) Agung, ia mengatakan bahwa: 
"Sejak kecil saya pernah tinggal di asrama Yonif 303 euuuuu dan saya disana banyak melihat tentara yang sedang latihan lari sambil menyanyikan lagu-lagu TNI. Dari situlah saya mulai mencari dan mendownload lagu-lagu TNI, karena menurut saya lagu-lagu tersebut sangat membuat saya menggebu-gebu. Yaaaaa bisa dibilang saya juga merinding ngedengernya tapi keren juga gitu, seperti ada dorongan yang sangat besar ke diri saya. Dari situlah saya pun ingin dan memutuskan untuk bergabung menjadi seorang anggota TNI".

Sejak kecil informan pertama ini sudah tinggal di lingkungan militer atau di bataliyon. Lagu-lagu TNI yang di dengarkannya dulu membuatnya menjadi seorang yang disiplin dan rajin berlatih untuk menjadi seorang prajurit di masa yang akan datang. Lagu-lagu tersebut selalu ia putar untuk memberikan motivasi pada dirinya untuk selalu berlatih setiap saat. Lagu-lagu TNI memiliki lirik yang mudah di ingat dan di hafal serta isinya sangat mendalam sehingga dapat mampu memberikan dorongan yang begitu besar bagi orang yang mendengarkannya.

Tidak jauh berbeda dengan Agung, (informan 2) Aldi, ia memaparkan mengenai pengalamannya yaitu:

"Euuuu awal mula saya mengenal dunia militer karna saya sejak kecil dibesarkan di lingkungan militer jadi sejak kecil saya di didik secara militer oleh orang tua. Euuu peristiwa yang membuat saya tertarik menjadi seorang prajurit yakni diklaimnya pulau terluar Indonesia oleh negara tetangga, sehingga saya ingin menjaga kedaulatan NKRI jangan sampai jatuh kepada siapapun meskipun itu hanya sejengkal tanah".

Aldi sejak kecil memang sudah tinggal di lingkungan militer sehingga ia sudah terbiasa melihat orang yang mengenakan baju loreng. Selain itu, informan ke dua ini juga sangat peduli dengan apa yang pernah di beritakan di mana diklaimnya pulau terluar Indonesia oleh negara tetangga. Dari situlah ia ingin menjaga keutuhan kedaulatan negara Indonesia ini dengan mengabdikan dirinya kepada negara melalui TNI-AD.

Sama halnya dengan informan yang sebelumnya, (informan 3) Dwiyana memaparkan pengalamannya sebagai berikut:

"Dari kecil hingga sekarang saya berteman dengan temen-temen yang memiliki cita-cita menjadi seorang prajurit TNI euuu jadi saya termotivasi untuk menjadi prajurit TNI-AD dan berlatih setiap saat dalam menempuh prosesnya. Dari kecil juga saya sudah dididik oleh orang tua saya harus disiplin dan diarahkan harus menjadi prajurit TNI-AD. Trus saya juga seneng ngedengerin lagu-lagu TNI karna liriknya mudah di ingat jeung mudah dihafalkan. Yang paling suka ... lagu Mars TNI sama Hymne Kopasus, merinding setiap kali saya dengerin lagunya".

Tidak jauh berbeda dengan informan yang sebelumnya di mana dari kecil Dwi sudah tinggal di lingkungan militer. Seringnya mendengarkan lagu-lagu TNI membuatnya sangat tertarik untuk menjadi anggota TNI-AD. Menurutnya proses merupakan jalan menuju kesuksesan yang harus kita jalani dengan sungguh-sungguh karena setiap yang kita inginkan tidak ada hasil yang didapat secara instan.

Lain hal nya dengan (informan 4) Andrianto, ia memaparkan bahwa:

"Euuuuu saat masih kecil saya kagum liat ayah pakai seragam loreng saat akan berangkat dinas. Terus sejak kecil selalu ditanamkan hidup disiplin, selalu berlatih fisik. Euuu dari dulu sampai sekarang saya juga suka main game yang berbau perang trus suka nonton film action yang ada prajuritnya. Euuu trus saya juga kan pernah ikut pendidikan bela negara, di latih sama tentara, latihan fisik, dilatih kedisiplinan. Ya dari situlah saya mulai giat berlatih untuk bisa masuk TNI".

Makna Prajurit TNI-AD

Makna datang dari pemikiran setiap orang. Namun makna bisa berbeda-beda karena setiap orang memiliki pola pikir yang berbeda, sekalipun ada persamaan itu pun hanya sedikit. Berdasarkan hasil wawancara dengan para informan didapatkan hasil mengenai makna seorang prajurit TNI-AD.

Menurut (informan 1) Agung makna seorang prajurit dipaparkan sebagai berikut: 
"Makna seorang prajurit itu menurut saya euuu orang yang sangat disiplin dan selalu mengikuti aturan-aturan yang berlaku serta menjadi suatu kebanggaan bagi nusa dan bangsa. Trus prajurit juga euuu orang-orang yang dilatih untuk dipersiapkan menjaga dan melindungi dari ancaman negara lain. Euuuu trus prajurit juga orang yang jiwa korsanya tinggi dimana kesetiakawanan satu sama lain terjalin dengan baik. Baik buruknya dalam suatu kondisi tertentu, euuuuuu seorang prajurit harus saling merasakannya".

Agung mengatakan bahwa prajurit adalah sekelompok orang yang sangat disiplin dan mematuhi aturan-aturan. Selain itu Agung mengatakan bahwa prajurit adalah orang-orang yang dipersiapkan oleh negara untuk menjaga wilayah NKRI. Agung juga mengatakan prajurit memiliki solidaritas yang tinggi. Wawasan yang dimiliki oleh Agung mengenai seorang prajurit cukup luas di mana ia memang sudah lama mengenal dunia militer. Sehingga wawasannya mengenai militer sudah tidak diragukan lagi. Sama halnya dengan (informan 2) Aldi dimana ia mengatakan bahwa:

"Euuuu menurut saya prajurit TNI adalah rakyat Indonesia yang terpilih dan diberi tanggungjawab euuuu untuk mempertahankan NKRI. NKRI bagi prajurit adalah harga mati yang sangat bernilai. Euuu trus prajurit juga orang yang paling depan jika terjadi perselisihan antarnegara yang bisa mengakibatkan kontak fisik".

Menurut Aldi prajurit adalah warga sipil yang terpilih dan diberitanggung jawab untuk mempertahankan NKRI di mana merupakan harga mati yang harus dipertahankan. Seorang prajurit juga harus berada di depan dan dijadikan tameng negara. Menjadi prajurit memang tidak semudah yang dibayangkan karena banyak resiko yang sangat berat yang harus kita ambil dan kita hadapi. Mak dari itu kebanyakan orang yang masuk TNI adalah orang-orang yang sudah paham betul mengenai TNI. Tidak jauh berbeda dengan (informan 3) Dwiyana, ia mengatakan bahwa:

"Euuuuu prajurit teh seorang yang telah menjadi pembela negara atau pengabdi untuk negaranya yang siap kapanpun dimana negara membutuhkannya. Euuu trus seorang prajurit juga harus lebih mementingkan negaranya atau tugasnya dibandingkan keluarganya. Jadi euuu emang sulit sih jadi prajurit teh soalna kudu mempertaruhkan keluarga sendiri. Yaaaa itu emang udah resiko".

Dari pemaparan Dwi, bahwa prajurit adalah orang yang membela negara dan mengabdikan dirinya pada negara. Seorang prajurit juga harus siap kapanpun jika negara membutuhkannya. Pada dasarnya prajurit harus menomor satukan tugas dan negaranya dibandingkan keluarganya sendiri. Maka dari itu, seorang prajurit harus paham betul dengan tugas-tugasnya. Sama halnya dengan (informan 4) Andrianto, ia mengatakan bahwa:

"Makna prajurit TNI-AD menurut saya adalah euuuuu pengabdian pada negara, euuu menjaga keutuhan bangsa, dan euuuu itulah jiwa sebenarnya dari bangsa Indonesia bila kita menilik kebelakang bagaimana Indonesia merdeka. Euuuuuu menjadi prajurit TNI-AD adalah suatu kebanggaan terbesar dan sangat bermakna bagi kehidupan saya seindiri dan orang-orang yang terpilih".

Pembahasan

Pembahasan dari hasil penelitian juga didukung dengan hasil wawancara terhadap delapan informan yang telah peneliti tentukan dengan menyesuaikan kriteria yang telah peneliti buat sebelumnya untuk membatasi penelitian yang dilakukan. Ke delapan informan ini merupakan remaja yang pernah mengikuti seleksi calon prajurit TNI-AD tetapi gugur pada saat seleksi, namun mereka tetap berjuang untuk mencapai cita-citanya pada seleksi calon prajurit di tahun yang akan datang. 
Penelitian ini sebelumnya terlebih dahulu membuat persetujuan dengan informan untuk melakukan wawancara dan observasi sesuai apa yang telah disepakati bersama. Selain itu peneliti membuat jadwal wawancara dengan ke delapan informan tersebut untuk menyesuaikan aktivitas informan maupun peneliti agar mempermudah dan memperlancar jadwalnya wawancara dan penelitian yang dilakukan.

Pada sub bab ini, peneliti akan menguraikan dan mempertegas bahasan penelitian berdasarkan hasil-hasil yang diperoleh di lapangan, kemudian diperkuat oleh teori-teori. Peneliti akan membuat sebuah pembahasan mengenai motif remaja menjadi prajurit TNI-AD, pengalaman remaja sehingga memutuskan menjadi prajurit TNI-AD, dan makna prajurit TNIAD. Pembahasan juga merupakan interpretasi peneliti tentang hasil penelitian dengan analisis terkait teori dan konsep yang telah dikaji. Sebuah perilaku pastinya memiliki alasan-alasan yang melatarbelakanginya, alasan tersebut dapat disebut sebagai motif. Manusia sadar ataupun tidak, memiliki motif dibalik setiap kegiatan maupun dalam setiap interaksinya.

Motif merupakan suatu pengertian yang melingkupi semua penggerak, alasan, atau dorongan dalam diri manusia yang menyebabkan ia berbuat susuatu. Semua tingkah laku manusia pada hakikatnya mempunyai motif. Tingkah laku juga disebut tingkah laku secara refleks dan berlangsung secara otomatis dan mempunyai maksud-maksud tertentu walaupun maksud itu tidak senantiasa sadar bagi manusia. Motif-motif manusia dapat bekerja secara sadar, dan juga secara tidak sadar bagi diri manusia. (Gerungan. 2004:151-152.).

Banyaknya remaja yang mengikuti seleksi TNI-AD menjadi sebuah fenomena yang baru di masa sekarang dan menarik untuk diperbincangkan. Laki-laki maupun perempuan sangat antusias pada saat pembukaan seleksi TNI dan sangat serius dalam setiap tahap seleksi yang mereka tempuh. Dalam hal ini, para remaja pasti memiliki motif tersendiri dalam memutuskan menjadi seorang prajurit TNI-AD.

Penelitian ini menggunakan pendekatan fenomenologi Schutz (dalam Kuswarno, 2009:18) adalah melihat manusia dari pengalaman subjektifnya. Melalui pendekatan ini, peneliti akan mengungkapkan apa saja hal-hal yang menjadi motif remaja menjadi seorang prajurit TNI-AD di Korem 062/TN. Berdasarkan hasil wawancara yang dilakukan, peneliti mendapatkan hasil yang beragam mengenai motif remaja menjadi prajurit TNI-AD.

Pada penelitian ini, peneliti menemukan temuan-temuan di mana ada faktor-faktor yang sangat dominan dalam mempengaruhi pola pikir remaja sehingga mempengaruhi keputusannya. Salah satunya adalah faktor orang tua di mana orang tua sangat berperan aktif dalam membimbing dan mendidik anaknya agar kelak dewasa sesuai yang diingin oleh para orang tua. Pada dasarnya ke delapan informan dalam penelitian ini rata-rata orang tuanya adalah anggota TNI-AD yang masih aktif bekerja. Maka dari itu, pengaruh orang tua sangat besar dampaknya bagi anak-anaknya. Pada saat observasi partisipan, peneliti menemukan suatu hal yang unik di mana mimik wajah yang serius pada saat melakukan latihan fisik yang dilakukan oleh para informan.

Menurut Schutz bahwa objek penelitian ilmu sosial pada dasarnya berhubungan dengan interpretasi terhadap realitas. Jadi sebagai peneliti sosial, kita pun harus membuat interpretasi terhadap realitas yang diamati. Orang-orang saling terikat satu sama lain ketika membuat interpretasi ini (dalam Kuswarno, 2009:38). Menurut pemikiran Schutz, para informan memiliki salah satu atau kedua-keduanya dari kedua jenis motif yaitu motif untuk (in order motives) dan motif karena (because motives).

\section{Analisis Motif "Untuk" (in order to motives)}

Motif 'untuk' (in order to motives), artinya bahwa sesuatu merupakan tujuan yang digambarkan sebagai maksud, rencana, harapan, minat, dan sebagainya yang berorientasi pada masa depan. Dengan kata lain, jenis motif ini lebih kepada alasan seseorang melakukan tindakan sebagai usahanya menciptakan situasi dan kondisi yang diharapkan dimasa yang akan 
datang atau harapan dimasa yang akan datang. Masa depan atau mendatang disini adalah dimana informan yang memilih menjadi seorang prajurit TNI-AD.

Motif "untuk" informan menjadi prajurit TNI-AD yaitu cita-cita. Keinginan yang kuat sejak kecil karena pengaruh dari beberapa faktor, menjadikan kelak dewasa ia ingin menjadi seorang prajurit yang tangguh, beribawa dan penuh tanggung jawab. Cita-cita dari kecil yang dimiliki setiap orang pastilah ada faktor-faktor yang mempengaruhinya baik faktor eksternal maupun faktor internal. Seperti (informan 4) Andrianto di mana ia mengatakan bahwa motif dirinya menjadi seorang prajurit yakni karena cita-citanya dari kecil. Hal ini, juga dikarenakan ayahnya yang merupakan anggota TNI-AD. Selain itu cita-cita dari kecilnyalah yang membuatnya selalu bermimpi dewasa bisa menjadi seorang prajurit TNI-AD seperti ayahnya. Cita-cita bisa muncul semenjak kecil di mana anak-anak cenderung dengan mudahnya menangkap apa yang mereka lihat dan didengarnya. Faktor-faktor lain juga bisa saja mempengaruhi cita-cita seseorang.

Hal ini dipertegas oleh hasil wawancara dengan Serka Ngadirin selaku orang tua calon Andrianto. Beliau mengatakaan bahwa keinginan yang dimiliki anaknya menjadi prajurit memang sudah menjadi cita-citanya sejak kecil. Dari kecil Andrianto suka sekali memakai baju tentara, dan selalu bermimpi menjadi tentara. Cita-citanya itu membuat Andrianto serius melatih fisiknya sejak awal masuk sekolah menengah atas. Selain itu, karena Andrianto melihat ayahnya yang seorang anggota TNI sehingga ia termotivasi juga. Kebanyakan latar belakang yang dimiliki setiap calon hampir sama yaitu karena orang tuanya anggota TNI-AD dan adanya faktor lingkungan yang mendukungnya. Maka dari itu sudah terbentuk dari kecil dan dijadikan cita-citanya oleh mereka yang ingin menggapai tujuannya.

Motif ekonomi juga merupakan alasan mengapa banyaknya remaja ingin masuk ke dalam dunia militer. Seperti yang kita ketahui bahwa TNI pada masa sekarang sudah dijadikan mata pencaharian di mana penghasilan dan tunjangannya menjaminkan kehidupan seseorang hingga tua nanti. Berbeda pada saat sebelum tahun 2000, seseorang yang masuk ke dalam TNI bukan untuk mencari penghasilan untuk memenuhi kehidupannya, namun untuk mengabdi pada negara di mana pada masa itu Negara Indonesia sedang mengalami banyak krisis dari berbagai lini. Motif ekonomi ini sama halnya yang dikatakan oleh (informan 7) Sita di mana salah satu motifnya ingin menjadi prajurit TNI-AD adalah karena penghasilannya yang stabil. Selain itu juga tunjangan kelak di masa tua menjadikan alasannya. Jadi, motif Sita dikarenakan untuk menghidupi keluarganya di mana dewasa nanti ia berkeluarga dan mempunyai seorang anak. Ekonomi memang menjadi sebuah permasalahan yang sudah tidak asing lagi bagi setiap manusia. Pengahasilan setiap bulannya yang stabil dijadikan salah satu alasan di mana remaja ingin menjadi anggota TNI-AD.

$\mathrm{Hal}$ ini, diperkuat oleh hasil wawancara triangulasi narasumber dengan Peltu Dedi Ruhaedi Selaku Pelatih Binjasmil Korem 062/TN. Beliau mengatakan bahwa prajurit pada masa sekarang sudah dijadikan profesi tersendiri bagi kalangan banyak dikarenakan penghasilannya mampu menunjang sampai pensiun nanti. Pendapatan yang stabil setiap bulannya juga menjadikan mengapa pada masa sekarang banyak orang yang ingin menjadi prajurit TNI-AD. Setiap tahunnya, peningkatan pendaftaran TNI-AD sangat drastis. Hal ini menunjukan antusias para remaja sangat tinggi untuk masuk TNI. Namun hal itu tidak semudah yang dipikirkan, harus menempuh beberapa tahap seleksi untuk menjadi seorang prajurit TNI-AD.

\section{Analisis Motif "Karena" (because motives)}

Motif "karena" (because motives), artinya sesuatu merujuk pada pengalaman masa lalu individu, karena itu berorientasi pada masa lalu. Di era modern ini banyaknya remaja yang mulai melatih dirinya untuk bisa masuk ke dalam dunia militer khususnya pada TNI-AD. Mereka mulai meminati profesi ini dibandingkan dengan tahun-tahun sebelumnya di mana sangat jarang sekali diminati. Peristiwa ini membuat alokasi pendaftaran prajurit semakin 
meningkat setiap tahunnya. Peningkatan yang sangat drastis ini memiliki dampak positif bagi negara untuk menambah personil dan menjaga kedaulatannya. Keputusan ini pasti memiliki motif tersendiri bagi setiap individu. Berdasarkan hasil wawancara yang dilakukan, peneliti mendapatkan hasil mengenai motif "karena" remaja menjadi prajurit TNI-AD.

Motif rasa nasionalisme yang timbul dari dirinya membuat seseorang rela mengabdikan dirinya pada negara. Seperti yang dikatakan Aldi (informan 2), motifnya karena rasa nasionalisme yang sangat tinggi. Keinginannya mengabdi pada negara sangat kuat dalam dirinya sehingga Aldi ingin menjadi seorang prajurit yang rela berkorban demi bangsa dan negaranya. Baginya, NKRI adalah harga mati yang harus dijaga sampai kapanpun. Seseorang yang rela mati demi negara pastilah memiliki jiwa nasionalisme yang dipegang teguh dalam dirinya. Rasa nasionalisme ini bisa timbul kepada setiap orang yang memang memiliki pengalaman-pengalaman yang berbau sejarah tentang suatu negara. Pada masa sekarang tumbuhnya jiwa nasionalisme sangatlah sulit dibanding pada masa sebelum revolusi, namun salah satu alasan remaja menjadi seorang prajurit karena adanya panggilan hati sehingga ia memutuskan untuk menjadi anggota TNI-AD.

Selain itu juga, motif keluarga sangat berperan aktif dalam menentukan tujuan hidup seseorang. Seperti Rani (informan 6), motif ia ingin menjadi prajurit karena ke dua orang tuanya merupakan anggota TNI-AD. Adanya sebuah pembalajaran yang ia dapatkan dengan cara melihat dan mendengar dari ke dua orang tuanya dapat mempengaruhi pola pikirnya, sikap, dan perilaku di mana bisa berpengaruh terhadap keinginan maupun keputusannya untuk memiliki profesi yang sama seperti ayah dan ibunya. $\mathrm{H}$

al ini, seperti apa yang dikatakan oleh orang tuanya Rani di mana memang benar dari Rani kecil orang tuanya sudah memberikan pembalajaran bagi Rani agar kelak dewasa ia bisa meneruskan perjuangan ke dua orang tuanya. Maka dari itu motif yang paling dominan Rani memutuskan dirinya untuk menjadi seorang prajurit TNI-AD adalah keluarganya. Keluarga terutama orang tua adalah seseorang yang membimbing anak-anaknya untuk memiliki kepribadian yang baik dan orang tua juga dapat membentuk perilaku, dan keputusan yang dibuat oleh anaknya. Maka dari itu, peran orang tua sangat penting.

Motif keluarga yang dipaparkan menurut Rani ini diperkuat oleh hasil wawancara dengan triangulasi narasumber yaitu pelatih Binjasmil Peltu Dedi Ruhaedi, di mana motif keluarga bisa terjadi karena kebanyakan terinspirasi dari orang tuanya di mana adalah seorang anggota TNI. Dari kecil sudah melihat orang tuanya memakai seragam loreng dan dari situlah mulai muncul keinginannya. Hal tersebut membuat para remaja yang ditanya apa motif mereka masuk TNI, kebanyakan akan menjawab karena cita-cita dari kecil, hal ini membuktikan bahwa faktor keluarga sangat berpengaruh bagi kehidupan anaknya di masa yang akan datang.

Motif lingkungan sekitar juga sangat berpengaruh bagi remaja, di mana pergaulan dengan teman-temannya yang satu hobi ataupun satu lingkungan dapat mempengaruhi keputusannya di masa yang akan datang. Seperti yang katakana oleh Dwiyana (informan 3), motifnya ingin menjadi seorang prajurit TNI karena adanya pengaruh dari lingkungan bermain di mana kebanyakan temannya adalah para calon yang akan mengikuti selek prajurit TNI-AD. Motivasi dari lingkungannya dapat mempengaruhinya perlahan demi perlahan, namun seiring dengan waktu secara tidak disadari seseorang akan mengikuti teman-temannya karena sudah merasa nyaman dan satu tujuan. Lingkungan yang mendukung dapat memperkuat keputusan seseorang untuk bertindak. Lingkungan di mana rata-rata adalah anak-anak tentara atau remaja yang ingin menjadi seorang tentara dapat sangat mempengaruhi pola pikirnya di mana hal ini dapat berdampak pada tumbuhnya suatu keinginan tertentu untuk agar dapat menyesuaikan dengan lingkungannya.

Motif lingkungan ini juga diperkuat oleh hasil wawancara dengan Peltu Dedi Ruhaedi. Selain faktor keluarga, faktor lingkungan sangat mempengaruhi keputusan seseorang terhadap 
pengambilan keputusannya. Lingkungan yang mendukung akan membuatnya beradaptasi untuk bisa mengikutinya (Sarwono, 2008: 14). Misalnya seseorang yang dari kecil sudah tinggal di asrama militer akan dengan mudah mengikuti kebiasaan lingkungannya. 


\section{Analisis Pengalaman}

Pada analisis pengalaman dalam penelitian ini, peneliti menggunakan fenomenologi menurut Husserl. Fenomenologi diartikan sebagai 1) pengalaman subjektif atau pengalaman fenomenologikal; 2) suatu studi tentang kesadaran dari perspektif pokok dari seseorang (Husserl). Istilah fenomenologi yang sering digunakan sebagai anggapan umum untuk menunjuk pada pengalaman subjektif dari berbagai jenis dan tipe subjek yang ditemui. Dalam arti yang lebih khusus, istilah ini mengacu pada penelitian terdisiplin tentang kesadaran dari perspektif pertama seseorang. Sebagai suatu disiplin ilmu hal ini dikemukakan oleh Edmund Husserls (1859-1938) seorang filsuf Jerman (Moleong 2010).

Pengalaman pada dasarnya melalui suatu proses di mana rangsangan-rangsangan dari luar seperti cahaya untuk mata, bunyi untuk telinga, dan bau untuk hidung melalui alat-alat pengamatan kita (pancaindra) diteruskan ke pusat-pusat tertentu di dalam otak yang lalu menafsirkan pengamatan tadi. Kita mengamati sesuatu karena ada minat perhatian yang mengadakan seleksi diantara semua rangsangan yang terdapat di lingkungan kita untu diamati atau ditafsirkan, kecuali kita kerahkan minat perhatiankita dengan khusus untuk menafsirkan semuanya (Nurhadi, 2015: 35). Minat perhatian itu ditentukan oleh struktur kebutuhan atau motif yang terdapat pada seseorang. Jadi, sebenarnya motif-motif kita, melalui minat dan perhatian kita, mempunyai peranan besar dalam menentukan apa yang kita lihat, dengar, dan amati di lingkungan kita (Gerungan, 2010:156-158).

Hasil dari penelitian mengenai pengalaman para remaja dalam memutuskan menjadi prajurit TNI-AD yaitu karena rata-rata informan dari kecil sudah tinggal di lingkungan asrama militer. Keterbiasaannya melihat dan mendengarkan suara latihan seorang prajurit, memberikan pendidikan yang secara tidak disengaja masuk ke dalam diri seorang anak. Pada dasarnya, seorang anak akan lebih mudah menerima pembelajaran dari apa yang mereka lihat dan dari apa yang mereka dengar. Sama halnya dengan apa yang dikatakan oleh (informan 1) Agung, ketika kecil ia pernah tinggal di asrama Yonif 303. Setiap hari ia selalu melihat para prajurit berlatih sambil menyanyikan lagu-lagu TNI. Hal ini membuktikan bahwa, sebuah tempat tinggal dapat mempengaruhi seseorang untuk memutuskan suatu keinginannya di masa yang akan datang. Lingkungan asrama yang sehari-harinya di lihat orang seorang anak akan dapat mempengaruhinya dalam segala hal termasuk tujuannya kelak dewasa. Lingkungan yang dominan ini akan sangat berdampak bagi remaja karena sudah tidak aneh melihat dan mendengar tentara yang sedang latihan, dan akan timbulnya rasa keingin tahuan yang begitu dalam dan timbulnya motivasi-motivasi tertentu.

Hal ini dipertegas oleh hasil wawancara dengan Sertu Agus Supriatna selaku orang tua (informan 1) Agung Prawira Subagja. Beliau mengatakan bahwa keinginan Agung menjadi prajurit TNI-AD seperti beliau dikarenakan dari kecil Agung sudah tinggal di asrama militer. Ketika beliau masih ditugaskan di Yonif 303 dan tinggal di asrama, Agung sering bermain dan melihat orang-orang yang memakai seragam loreng, dan dari situlah mulai timbul keinginnannya menjadi prajurit TNI-AD sampai sekarang.

Adapula pengalaman yang mempengaruhi keputusan remaja menjadi prajurit TNI-AD yaitu karena pengalaman semasa duduk di bangku sekolah. Keaktifan seorang murid selain dilihat aktif di kelas juga dapat dilihat aktif mengikuti organisasi-organisasi. Seperti yang dikatakan oleh Rani (informan 6) di mana mereka ia ketika duduk di bangku SMA sangat aktif dalam berorganisasi terutama mengikuti organisasi Paskibra. Penerapan latihan yang dilakukan Paskibra sama halnya pelatihan yang digunakan oleh militer. Disiplin menjadi hal yang utama bagi anggota Paskibra. Selama menjadi anggota Paskibra, Rani dilatih langsung oleh seorang tentara, dari situlah ia mulai mengerti dan menjadi lebih tertarik untuk menjadi seorang prajurit TNI-AD. Ketertarikannya ini tidak begitu saja dating secara dengan tiba-tiba namun dengan alasan yang jelas di mana setiap hari Rani mengikuti Paskibra, di mana Paskibra 
menanamkan kedisiplinan yang sangat tinggi bagi para anggotanya. Organisasi juga dapat memberikan hal positif bagi remaja karena membuat remaja jadi lebih aktif dalam segala hal.

Selain itu, pengalaman yang mempengaruhi remaja menjadi prajurit TNI-AD yaitu karena pengaruh Game Online Action. Semakin berkembangnya dunia teknologi tidak dipungkiri lagi bahwa penggunaan gadget sudah menjadi kebutuhan primer bagi setiap orang, terlebih banyaknya aplikasi-aplikasi yang mendukung pengguna gadget sangat memanjakan usernya salah satunya game online. Game Online menjadi salah satu faktor utama di mana seseorang aktif menggunakan gadget. Sama halnya dengan apa yang dikatakan oleh Fadly (informan 5), ia suka bermain Game Online terutama yang berhubungan dengan perang. Layaknya seorang prajurit di dunia maya Fadly gemar sekali memainkannya, menurutnya, bermain game dapat menambah motivasi dirinya untuk menjadi seorang prajurit di dunia nyata. Hal ini menunjukan bahwa motivasi yang di dapatkan oleh setiap individu bisa didapatkan melalui apa saja termasuk melalui game online yang dimainkannya. Bermain game bisa mempengaruhi pola pikirnya juga karena bermain game akan berdapak kecanduan dan ingin menjadi apa yang dimainkannya di dunia maya. Namun, seringnya bermain game bisa berdampak kepada rusaknya pancaindra penglihatan karena terlalu lama melihat layar monitor dan menurunkan minat untuk belajar. Jika tidak dapat mengontrolnya, akan menimbulkan hal yang negatif bagi penggunanya.

Pengalaman Fadly ini, diperkuat oleh hasil wawancara dengan triangulasi narasumber Kapten Inf. Ade Army Subarkah selaku Dantim Intel Korem 062/TN. Adapun faktor yang mempengaruhi remaja menjadi prajurit TNI karena banyaknya tayangan-tayangan mengenai militer di televisi yang membuat para remaja dapat dengan mudah tertarik dengan dunia militer. Selain itu juga game online yang merajalela di jaman gadget sekarang ini dapat mempengaruhi pola pikir seseorang. Pengaruh game online dapat dengan mudah memasuki otak seseorang dalam segala hal bahkan sampai terbawa ke dunia nyatanya.

Peneliti juga mendapatkan hasil lain mengenai pengalaman bahwa adanya didikan dari keluarga sejak kecil menjadi anak tersebut memilih menjadi seorang TNI kelak dewasa. Hal ini sama dengan apa yang dialami oleh Aldi (informan 2), dari kecil ia sudah didik secara militer, disiplin menjadi prioritasnya terutama disiplin pada waktu. Baginya waktu adalah segalanya, jika kita menyia-nyiakan waktu itu sama halnya kita menyia-nyiakan proses yang kita tempuh untuk masa depan kita. Sejak kecil Aldi memang sudah diarahkan oleh ke dua orang tuanya agar kelak dewasa nanti ia bisa meneruskan perjuangan ayahnya menjadi prajurit TNI-AD. Didikan orang tua sangat berperan aktif bagi anaknya di mana anak akan mengikuti semua keinginan orang tuanya karena alasan untuk membanggakannya. Seorang anak pasti tidak ingin mengecewakan orangtuanya maka dari itu didikan orang tua kepada anaknya akan langsung bisa diterima oleh anak jika faktor-faktor lain mendukung keadaannya.

Apa yang dipaparkan oleh Aldi ini juga dipertegas oleh orang tuanya yaitu Pelda Didi, menurut beliau keluarga tidak memberikan tuntutan kepada Aldi agar menjadi tentara, namun keluarga hanya memberikan masukan sedikit kepada Aldi, jika ia dewasa dan mencari kerjaan haruslah yang dapat menunjang kehidupannya sampai pensiun nanti. Sejak kecil orang tua Aldi memang sudah menanamkan disiplin pada anak-anaknya, karena menurutnya, disiplin adalah hal yang utama dalam mencapai kesuksesan. Motivasi terbesar yang dimiliki Aldi adalah ketika kakanya lulus masuk Kowad Bintara PK, Aldi mulai serius berlatih untuk menyusul kakanya. Dari situlah keinginannya bulat untuk menjadi seorang tentara.

Analisis Makna

Makna dapat memperlihatkan bahwa setiap individu memiliki kemampuan berpikir sesuai dengan kemampuan serta kapasitas kognitif atau muatan informasi yang dimilikinya. Oleh karena itu, makna tidak akan sama atas setiap individu walaupun objek yang dihadapinya 
adalah sama. Pemaknaan terjadi karena cara dan proses berpikir adalah unik pada setiap individu yang akan menghasilkan keragaman dalam konstruksi makna (George, 2007: 6).

Analisis penelitian ini sesuai dengan definisi makna menurut George. Secara garis besar menurut hasil wawancara yang dilakukan peneliti, informan memiliki makna tersendiri mengenai makna seorang prajurit TNI. Makna tersebut bagi Agung (informan 1) yaitu sekumpulan orang yang memiliki jiwa korsa tinggi di mana satu sama lain saling membutuhkan dan saling membantu dalam keadaan apapun. Jiwa korsa yang dimiliki oleh setiap prajurit tak luput dari didikan yang sangat disiplin yang diterima oleh para prajurit selama mengikuti Diksar (Pendidikan Dasar) selama beberapa bulan. Hal ini, menimbulkan rasa sepenanggungan antara prajurit sehingga terbentuk jiwa korsa yang sangat tinggi. Jiwa korsa ini sangat penting dimiliki oleh setiap prajurit dikarenakan prajurit harus kompak, harus bekerjasama, dan harus saling membantun satu sama lain. Dalam bertugas seorang prajurit tidak ada yang meninggalkan temannya walaupun pada saat kondisi yang sangat tertekan.

Makna prajurit TNI bagi Aldi (informan 2) adalah rakyat Indonesia yang terpilih dan diberi tanggung jawab untuk mempertahankan NKRI. Rakyat sipil yang terpilih ini merupakan seorang prajurit yang telah lulus mengikuti seleksi TNI yang diselenggarakan oleh Kodam disetiap wilayahnya masing-masing. Seleksi tersebut dibuat untuk memilih calon prajurit yang terbaik dari yang terbaik. Karena seorang prajurit harus memiliki fisik yang mampu menunjangny dalam bertugas selain itu seorang prajurit harus memiliki wawasan yang luas. Seleksi yang dilakukan oleh pihak militer ini bertujuan untuk menyaring penerus bangsa yang berkualitas, berkuantitas untuk meneruskan perjuangan para pahlawannya untuk menjaga kedaulatan NKRI. Maka dari itu, seleksi yang diselenggarakannyapun sangatlah banyak dan sulit, karena ada beberapa seleksi yang harus ditempuh dan dilewati oleh para calon agar dapat menjadi seorang prajurit TNI-AD.

Selain itu, menurut Rani (informan 6) makna seorang prajurit yaitu orang yang rela meninggalkan keluarganya demi mengorbankan hidupnya untuk NKRI. Tugas prajurit memanglah sangat sulit, karena seorang prajurit harus mengedepankan tugasnya dibandingkan dengan apapun termasuk keluarganya sendiri. Dalam keadaan apapun jika perintah tugas telah dikeluarkan, tanpa terkecuali entah itu keluarganya sedang ada yang sakit, tugas harus segera dilaksanakan. Memang berat, namun itu adalah salah satu resiko yang harus diambil oleh setiap orang menjadi prajurit. Prajurit juga manusia, mereka pasti memerlukan keluarga sebagai kotivasi dalam bertugasnya, namun tugas memang menjadi nomor utama bagi seorang prajurit, terkadang harus meninggalkan keluarga secara mendadak dalam keadaan apapun. Maka dari itu, seorang prajurit juga harus bisa mengatur waktu antara tugas dengan negaranya.

Adapula makna menurut Sita (informan 7) bahwa seorang prajurit merupakan profesi yang gajinya kecil namun menanggung resiko yang sangat besar. Pada dasarnya seseorang yang masuk ke dalam dunia militer berarti mereka ingin mengabdikan dirinya pada negara, namun pada masa sekarang TNI sudah dijadikan sebuah lapangan pekerjaan, di mana seseorang masuk menjadi prajurit TNI untuk mendapatkan penghasilan bagi menghidupi keluarganya. Hal ini menjadi fenomena yang baru di era modern ini, berbeda pada saat sebelum tahun 2000 di mana TNI merupakan orang-orang yang rela mati untuk negara tanpa mengharapkan bayaran yang tinggi. Memang pada saat ini juga penghasilan yang dimiliki oleh setiap prajurit TNI tidaklah besar, bahkan bisa dibilang kecil dibandingkan dengan penghasilan dalam bidang pekerjaan yang lain. Namun penghasilan yang kecil ini menanggung beban dan resiko yang sangat besar bagi setiap prajurit. Tapi hal ini tidak membuat para remaja menjadi pesimis, justru malah sebaliknya. Semakin besar resiko yang dihadapi semakin optimis para remaja untuk menjadi seorang prajurit TNI. Rata-rata remaja yang ingin masuk menjadi seorang prajurit adalah remaja yang suka dengan tantangan dan resiko yang sangat berbahaya bagi nyawanya sendiri. 
Menurut Widya (informan 8) makna prajurit yaitu sebuah profesi yang menanamkan kedisiplinan dan kesetiaan pada negara. Pemaknaan yang dipaparkan oleh Widya ini sesuai dengan wawasan yang dimiliki serta sesuai dengan pengalaman yang pernah ia lihat dan pernah ia dengar. Seorang prajurit dituntut untuk menghargai waktunya dan dituntut untuk disiplin dalam semua aspek. Seorang prajurit juga harus setia kepada negaranya, di mana setiap prajurit sudah diambil sumpahnya pada saat pendidikan dasar seuai yang tercantum dalam Sumpah Prajurit dan Sapta Marga. Dalam dunia militer disiplin menjadi hal yang utama dalam segala hal. Seorang prajurit dituntut untuk selalu menghargai waktu sedetik apapun itu, karena tiap detik waktu yang berjalan adalah detik-detik berharga yang dimiliki oleh setiap prajurit TNI. Kedisiplinan ini adalah hal yang utama bagi prajurit TNI, maka dari itu seorang prajurit harus bisa mengefektifkan sebaik mungkin waktunya yang dimilikinya. Berdasarkan paparan hasil penelitian dan pembahasan, penulis menyajikan bagan kerangka konseptual penelitian ini yang terlihat pada bagan 1 , yaitu: 


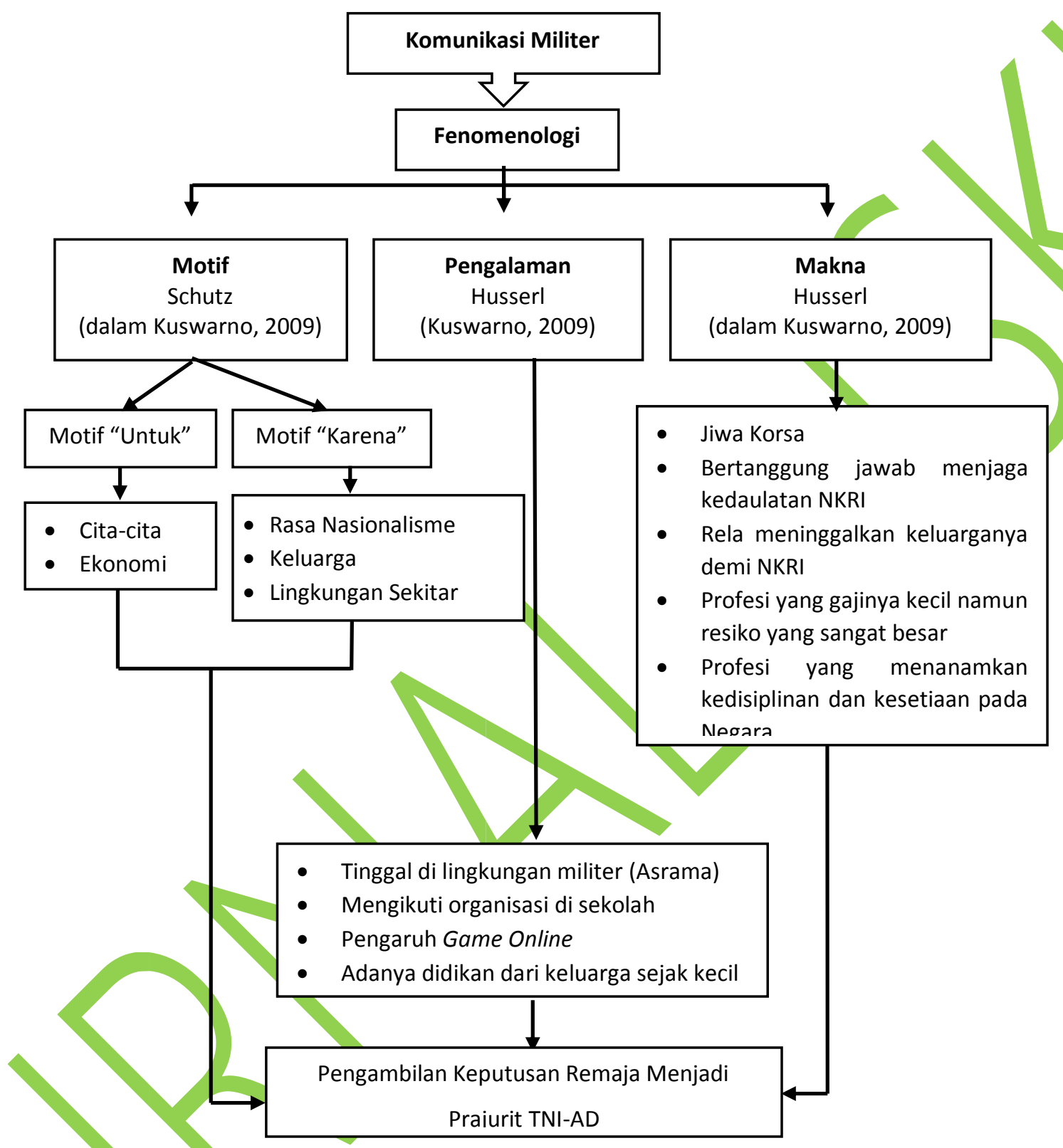

Gambar 1. Model Kerangka Konseptual Hasil Penelitian

Sumber: Model Kategorisasi dari Hasil wawancara (diadopsi dari informan tahun 2017) Schutz (dalam Kuswarno, 2009); Husserl (Kuswarno, 2009)

\section{SIMPULAN DAN SARAN}

Simpulan

Berdasarkan hasil penelitian yang telah dikemukakan, dapat ditarik suatu kesimpulan atas penelitian "Komunikasi Militer Pada Remaja Dalam Mengambil Keputusan Menjadi Prajurit TNI-AD, yaitu:

a. Motif remaja menjadi prajurit TNI-AD dibagi menjadi dua motif yaitu motif 'untuk' dan motif 'karena'. Motif 'untuk remaja ini dikarenakan adanya tujuan cita-citanya dari kecil di mana telah mereka idam-idamkan sejak lama. Selain itu juga, adanya faktor ekonomi yang mempengaruhi keputusan mereka. Sedangkan, motif 'karena' informan dikarenkan 
adanya rasa nasionalisme yang tumbuh dalam dirinya sehingga rela berkorban demi negara melalui jalur TNI-AD. Adapula karena faktor keluarga, di mana rata-rata orang tua dari informan adalah anggota TNI-AD. Motif keluarga ini sangat berperan aktif dalam menentukan tujuan hidup seorang anak yang kelak akan tumbuh dewasa. Selain itu juga, karena motif lingkungannya di mana informan dari kecil sudah tinggal di lingkungan militer (Asrama TNI-AD). Hal ini membuatnya terbiasa dengan situasi di lingkungannya sehari-hari. Lingkungan ini jugalah yang mempengaruhi pola pikir para informan dari kecil hingga sekarang, di mana anak kecil akan dengan mudah meniru sesuatu yang ia lihat dan ia dengar.

b. Pengalaman calon prajurit (remaja) sehingga memutuskan menjadi prajurit TNI-AD dikarenakan sejak kecil sudah tinggal di lingkungan militer (Asrama). Keseharian mereka melihat orang-orang yang memakai seragam loreng menjadikan mereka terbiasa dengan suasana seperti itu. Selain itu juga, aktif dalam berorganisasi di sekolah terutama dalam oranganisasi seperti Paskibra maupun Pramuka menjadikan mereka lebih disiplin dalam segala hal. Keaktifannya berorganisasi dijadikan dasar bagi mereka yang kelak ingin menjadi seorang prajurit yang tangguh. Adapula pengaruh Game Online action khususnya game perang yang saat ini merajalela dan bisa diakses dengan mudah membuat seseorang tertarik untuk menjadi seperti yang mereka mainkan di dunia maya. Adapula didikan dari kecil dari keluarga di mana anaknya harus menjadi seperti orang tuanya kelak dewasa. Didikan yang dilakukan orang tua kepada anaknya sangat mempengaruhi pola pikir dan keputusannya di masa yang akan datang. Karena seorang anak akan dengan mudah mengikuti perkataan orang tuanya.

c. Makna prajurit TNI-AD bagi remaja beragam-ragam, hal ini dikarenakan tergantung pada pengetahuan yang mereka miliki masing-masing. Makna prajurit TNI-AD yang pertama adalah seseorang yang memiliki Jiwa Korsa yang sangat tinggi. Saling merasakan kesulitan satu sama lain menjadikan seorang prajurit solid. Prajurit juga bisa dikatakan sebagai rakyat sipil yang terpilih dan diberi tanggung jawab untuk menjaga kedaulatan NKRI. Prajurit harus memiliki fisik yang bugar dan memeiliki pengetahuan yang luas dalam mempertahankan negara ini. Tidak sembarang orang bisa masuk, maka dari itu hanya orang-orang terpilih saja yang bisa menjadi anggota TNI-AD. Selain itu, seorang prajurit harus rela meninggalkan keluarganya demi mengorbankan hidupnya untuk NKRI. Memang keluarga dijadikan yang ke dua namun itu memang sudah resiko seorang prajurit. Adapula prajurit itu adalah suatu profesi yang gajinya kecil namun menanggung resiko yang sangat besar, bahkan nyawa bisa menjadi taruhannya. Seorang prajurit juga bisa di makna sebuah profesi yang menanamkan kedisiplinan dan kesetiaan pada negara. Maka dari itu, pada saat pelantikan, seorang prajurit akan di ambil sumpahnya sesuai dengan isi dalam sumpah prajurit dan sapta marga.

Saran

a. Saran bagi remaja yang melakukan proses pelatihan berupa latihan fisik seperti lari, pull up, shit up, push up, shuttle run, dan renang harus didasari dari keinginan sendiri supaya hasilnya maksimal.

b. Peran orang tua dalam hanya memberikan arahan dan tidak dilakukan paksaan kepada anaknya untuk daftar menjadi prajurit.

Implikasi bagi dunia akademik khususnya ilmu komunikasi, bisa memberikan warna keilmuan, sebab kajian tentang komunikasi militer masih sedikit. 
JURNAL LISKI | Vol. 4. No. 1 | 2018

$\longrightarrow$ 


\section{DAFTAR PUSTAKA}

Buku:

George Ritzer dan Douglas J. Goodman. 2007. Teori Sosiologi Modern. Jakarta: Kencana.

Gerungan. 2004. Psikologi Sosial. Bandung: Refika Aditama.

2010. Psikologi Sosial (Edisi Revisi). Bandung: Refika Aditama.

Kuswarno, E. 2009. Metode Penelitian Komunikasi: Fenomenologi, Konsepsi, Pedoman dan Contoh Penelitiannya. Bandung: Widya Padjadjaran.

Moleong, L. J. 2010. Metodologi Penelitian Kualitatif Edisi Revisi. Bandung: Remaja Rosdakarya.

Mulyana, Deddy. 2007. Metodologi Penelitian Kualitatif. Bandung: Remaja Rosdakarya.

Lestari, P. dkk. 2012. Komunikasi Militer Dan Ketahanan Nasional: Membangun Kembali Kedaulatan dan Kepentingan Nasional NKRI. Jakarta: ASPIKOM.

Nurhadi, Zikri Fachrul. 2017. Teori Komunikasi Kontemporer. Depok: Kencana.

Nurhadi, Zikri Fachrul. 2015. Teori -Teori Komunikasi (Teori Komunikasi Dalam Perspektif Penelitian Kualitatif). Bogor: Ghalia Indonesia.

Sarwono, S. W. 2008. Psikologi Remaja. Jakarta: Raja Grafindo Persada.

Sugiyono. 2013. Memahami Penelitian Kualitatif. Bandung : Alfabeta.

Jurnal (Sumber Internet):

Riris Dwi Setianing. (2015). Pola Asuh Anak Pada Keluarga Militer. Universitas Brawijaya. Diunduh pada tanggal 10 Maret 2017. Pukul 09.30 WIB. http://imsos.studentjournal.ub.ac.id/index.php/jmsos/article/download/81/104

Ririn Indraswari. (2010). Strategi Pencitraan Dinas Penerangan TNI-AU Dalam Kasus Kecelakaan Pesawat Militer Di Indonesia. Diunduh pada tanggal 11 Juni 2017. Pukul 09:05 WIB.

http://www.e-jurnal.com/2017/02/strategi-pencitraan-dinas-penerangan.html Website:

https://elqorni.wordpress.com/2014/02/17/pengambilan-keputusan-decision-making/.

Diakses pada tanggal 27 Februari 2017. Pukul 14.33 WIB.

https://id.wikipedia.org/Wiki/Tentara Nasional Indonesia Angkatan Darat. Diakses pada tanggal 27 Februari 2017. Pukul 14.13 WIB.

https://id.Wikipedia.org/wiki/Akademi Militer. Diakses pada tanggal 27 Februari 2017. Pukul 13.35 WIB. 